\title{
OBSERVATIONS ON THE INTERVENTION OF NATO IN KOSOVO
}

\author{
C. Jura
}

\section{Cristian Jura}

"Dimitrie Cantemir" Christian University, Bucharest, Romania

*Correspondence: Cristian Jura, 110 Icoanei Street, $2^{\text {nd }}$ district, Bucharest, Romania

E-mail: cristianjura@ yahoo.com

\begin{abstract}
On the date of June $12^{\text {th }} 1998$, the North-Atlantic Council, gathered on the level of the ministers of defense, required the evaluation of the possible additional measures which NATO could take under the conditions of aggravation of the crisis from Kosovo. Consequently, on the date of October $13^{\text {th }} 1998$, pursuant to the aggravation of the situation, the North-Atlantic Council authorized orders of activation for the air attacks. This measure is meant to support the diplomatic efforts in order to determine the regime of Miloşevici to withdraw the forces from Kosovo, to cooperate for the end of violence and to facilitate the return of refugees to their homes. However, in the last moment, pursuant to other diplomatic initiatives of the officials of NATO and United States, the president Miloşevici accepted to collaborate, and the air attacks were cancelled
\end{abstract} 1203.

Keywords: NATO, Kosovo, North-Atlantic Council, Security Council, Resolution

\section{Introduction}

The Kosovo region enjoyed a high degree of autonomy within the former Yugoslavia until 1989, when the Serbian leader Slobodan Milossevici changed the status of the region, withdrawing its autonomy and passing it under the direct control of Belgrade, the Serbian capital. The Albanian Kosovarians strongly opposed to this decision. During the year 1998, the open conflict between the military forces and the Serbian police forces and those of Albanian Kosovarians caused the death of over 1,500 of Albanian Kosovarians and chased away 400,000 persons from their home. The overcome of conflict, the humanitarian consequences and the risk of extension of it in other countries as well caused a deep worry within the international community. The ignorance by the president Milossevici of the diplomatic efforts to amiable set the crisis and the destabilizing role of Albanian militant forces from Kosovo represented other reasons of worry ${ }^{l}$.

\section{Preliminary issues of the intervention of NATO}

On the date of May $28^{\text {th }} 1998$, the North-Atlantic Council ${ }^{2}$ gathered on the level of the ministers of foreign affairs, determined the two major objectives of NATO related to the Kosovo crisis, namely:

\footnotetext{
${ }^{1}$ http://www.msz.gov.pl/editor/files/docs/DPB/polityka_bezpieczenstwa/NATO_handbook.pdf.

${ }^{2}$ The North-Atlantic Council is formed of the permanent representatives of all member states, who are gathering at least once per week and represent the political authority with effective power of decision. The Council gathers as well on high level, in the presence of the ministers of foreign affairs, the ministers of defense or the heads of state and government, having the same authority and deciding power, and their decisions have the same status and the same validity, regardless the level of the meeting. The Council has an important public image and issues
} 
- to contribute to the acquirement of an amiable settlement of crisis, by the contribution to the reaction of the international community; and

- to promote the stability and security in the neighboring countries, mainly in Albania and in the former Yugoslavia Republic of Macedonia ${ }^{3}$.

On June $12^{\text {th }} 1998$, the North-Atlantic Council, gathered on the level of the ministers of defense, required the evaluation of the possible additional measures which NATO could take under the conditions of the aggravation of the crisis from Kosovo. Consequently, on the date of October $13^{\text {th }} 1998$, pursuant to the aggravation of the situation, the North-Atlantic Council authorized orders of activation for air attacks. This measure is meant to support the diplomatic efforts in order to determine the regime of Milossevici to withdraw the forces from Kosovo, to collaborate for the termination of violence and to facilitate the return of refugees to their homes. However, on the last moment, pursuant to other diplomatic initiatives of the officials of NATO and of the United States, the president Miloşevici accepted to collaborate, and the air attacks were cancelled ${ }^{4}$.

The Resolution 1199 of the Security Council of ONU expresses, among others, the deep concern related to the excessive use of force by the Serbian security troupes ant the Yugoslavian army and demanded the end of fire by both parties involved in the conflict ${ }^{5}$. In the spirit of the resolution, limits were established with respect to the number of Serbia forces in Kosovo and in the purpose of the operations performed by it, according to a separate agreement concluded with the Serbian government. In addition, it was agreed that OSCE institutes a Mission of verification in Kosovo (KVM) which shall deal with the observance of the conditions on field and that NATO determines a mission of air supervision. The determination of the two missions was approved by the Resolution 1203 of the Security Council of the United Nations. A few NATO non-member nations agreed to contribute to the mission of supervision. Coming in the support of OSCE, the Alliance constituted a special operative military force which could contribute to the emergency evacuation of KVM members, in case of a new conflict which would expose them to risk. This operative force was carried out in the former Yugoslavian Republic of Macedonia, under the general control of the Supreme Commandant of the Allied Forces in Europe ${ }^{6}$.

Despite all these measures, the situation from Kosovo changed at the beginning of 1999 s, pursuant to some actions of challenge came from both parties and to the excessive and disproportionate use of force by the army and special Serbian police. A part of these incidents were stopped by the mediation efforts of OSCE inspectors, but on the half of January, the situation got worse, pursuant to the escalade of the Serbian offensive against the Albanians from Kosovo. New international efforts were undertaken in order to quicken the search of a peaceful solution of conflict. The six nations of the Group of Contact, incorporated in 1992 at the Conference of London for the former Yugoslavia, France, Germany, Italy, United Kingdom, Russia and the United State, gathered on the date of January $29^{\text {th }}$. It was decided the emergency organization of negotiations between the parties involved in conflict, which were to be carried out by international mediation. NATO supported and reinforced the efforts of the Group of Contact, approving on the date of January $30^{\text {th }}$ the use of air attacks on need

declarations and handouts, which explain to the wide public and the governments of the states which are not NATO members, the NATO orientations and decisions.

${ }^{3}$ http://www.nato.int/kosovo/history.htm.

${ }^{4}$ Ibidem.

5 Anca Păiu $\square$ escu, Nicoleta-Elena Buzatu, State's Recognition and Succesion Act as Contemporary Issues in International Relationships. Case Kosovo, The $18^{\text {th }}$ International Scientific Conference "THE KNOWLEDGE BASED ORGANIZATION", Sibiu, România, 14-16 iunie 2012, KBO Conference Proceedings 2 - Economic, Social and Administrative Approaches to the Knowledge - Based Organisation, "Nicolae Bălcescu” Land Forces Academy Publishing House, pp. 748-753.

${ }^{6}$ Ibidem. 
and transmitting a warning to both parties involved in conflict. These initiatives culminated with a first round of negotiations at Rambouillet, near Paris, between February $6^{\text {th }}-23^{\text {rd }}$ followed by a second round in Paris, between March $15^{\text {th }}-18^{\text {th }}$. At the end of the second round of discussions, the delegation of Albanian Kosovarians signed the peace agreement proposed, and the discussions ended without a similar signature to be obtained from the Serbian delegation ${ }^{7}$.

Immediately afterwards, the Serbian police and military forces intensified the operations against the Albanians ethnics from Kosovo, bringing troupes and additional tanks in the region, within a flagrant breach of the agreement from October. Before such systematic offensive, dozens of thousands of persons abandoned their homes ${ }^{8}$.

\section{consequences \\ II. Air campaign of NATO in Kosovo - Allied Force Operation and its \\ On March $20^{\text {th }}$, the OSCE mission of verification from Kosovo was withdrawn from} the region, due to the fact that the obstructions of Serbian forces restricted its activity. The ambassador of the United States, Richard Holbrooke, went to Belgrade, in a last attempt to convince the president Miloşevici to end the attacks over the Albanian Kosovarians, in order to avoid the imminent air attacks of NATO. Miloşevici refused to submit, thus, on March $23^{\text {rd }}$ was provided the order to start the air attacks (Allied Force Operation).

The Allied Force Operation lasted 78 days, between March $24^{\text {th }}$ and June $10^{\text {th }} 1999$, when the air forces of NATO performed 38,000 missions, out of which 10,484 bombardment raids (initially against the military objectives, then extended over the industrial installations and the Yugoslavian infrastructure), as well as 2,700 missions against Serbian anti-air defense. Undertaken without any decision of ONU Security Council, condemned by Russia and China, the operations in the air space of Yugoslavia represented the first military intervention in the history of NATO. If NATO forums acknowledged the loss of only two aircrafts, without claiming the disappearance of any military, the bombardments caused 545 deaths among the Yugoslavian army and 2,000 victims among the civil population. Also, the air campaign of NATO severely affected the economy of Yugoslavia, causing important destructions of goods, factories, refineries, bridges, implicitly the blockage of fluvial traffic on Danube ${ }^{9}$.

The NATO objectives related to the conflict from Kosovo were set forth in the declaration of the extraordinary meeting of the North-Atlantic Council, organized at the seat of NATO on April 12 $2^{\text {th }} 1999$, and they were acknowledged by the chiefs of state and by the government from Washington, on April $23^{\text {rd }}$ 1999:

- controlled termination of all military actions and immediate termination of violent and repression actions;

- withdrawal from Kosovo of police, military and paramilitary forces;

- staying in Kosovo of an international military presence;

- safe and unconditional repatriation of all refugees and persons deported and the free access of the organizations of humanitarian aid with a view to assist them;

- determination of a political frame-commitment for Kosovo in terms of the agreements from Rambouillet, in compliance with the international laws and the Charta of United Nations ${ }^{10}$.

When these conditions were agreed by the president Miloşevici, the North-Atlantic Council agreed on suspending the air campaign ${ }^{11}$.

\footnotetext{
${ }^{7}$ http://www.msz.gov.pl/editor/files/docs/DPB/polityka_bezpieczenstwa/NATO_handbook.pdf.

${ }^{8}$ Ibidem.

${ }^{9} \mathrm{http}: / / \mathrm{www}$.jointophq.ro/cdmopi/teatreoperatii/kosovo/.

${ }^{10} \mathrm{http} / / / \mathrm{www}$.nato.int/kosovo/repo2000/report-en.pdf.

${ }^{11}$ Ibidem.
} 
Thus, on June $10^{\text {th }} 1999$, after the end of the air campaign, the General Secretary of NATO, Javier Solana, announced that he had given instructions to the general Wesley Clark, Supreme Commandant of Allied Forces in Europe, concerning the termination of the air operations undertaken by NATO. This decision was adopted after consulting the NorthAtlantic Council and upon the confirmation by General Clark of the beginning of complete withdrawal of Yugoslavian forces from Kosovo. The withdrawal was performed in compliance with the technical-military agreement between NATO and the Federal Republic of Yugoslavia, in the evening of June $9^{\text {th }}$. The agreement was signed by the general lieutenant, Sir Michael Jackson, from NATO, and by the general colonel Svetozar Marjanovic, from the Yugoslavian army and by general lieutenant Obrad Stefanovic from the Ministers of Home Affairs, from the governments of Federal Republic Yugoslavia and Serbia Republic. The withdrawal was also performed in terms of the disposals of the agreement concluded on the date of June $3^{\text {rd }}$ between Federal Republic Yugoslavia and the special representatives of the European Union and Russia ${ }^{12}$.

On the same date of June $10^{\text {th }}$, the Security Council of the United Nations adopted the Resolution 1244, greeting the acceptance by the Federal Republic Yugoslavia of the principles for a political solution of the crisis from Kosovo, including the immediate termination of violence and the fast withdrawal of Yugoslavian military, police and paramilitary forces. The Resolution adopted with 14 favorable votes, none against, and one abstention (China), announced the decision of the Security Council to determine a civil and security presence in Kosovo, under the auspices of the United Nation. Acting under the Chapter VII of ONU Charta, the Security Council decided that the political solution of crisis was to be based on the general principles adopted on May $6^{\text {th }}$ by the ministers of foreign affairs from the Group of the seven industrialized countries and Russian Federation - Group of the $8-$ and on the principles included in the document presented in Belgrade by the special representatives of the Un European Union and Russia, which were accepted by the Federal Republic of Yugoslavia on June $3^{\text {rd }}$. Both documents were included as annexes to the Resolution ${ }^{13}$.

The principles included, among others, the immediate and verifiable termination of violence and of repression in Kosovo; withdrawal of military Yugoslavian military, police and paramilitary forces; development of an effective civil and security international presence with the substantial participation of NATO thereof and under unique control and command; incorporation of an intermarry administration; safe and free repatriation of all refugees; a political transformation to provide a substantial self-governing of Kosovo province; demilitarization of the Army of Liberation from Kosovo; and a global approach of the economic development of the crisis region ${ }^{14}$.

The Security Council authorized the member states and the main international organizations to determine the international presence of security and decided that its responsibilities include the discouragement of new hostilities, demilitarization of the Army of Liberation from Kosovo and insuring a safe environment for the return of refugees, and which may allow the international civil presence to carry out the activity. At the same time, the Security Council authorized the General Secretary of ONU to determine the international civil presence and demanded it to appoint a special representative in order to supervise the performance of such project in practice. Pursuant to adopting the Resolution 1244, the general Jackson, appointed as commandant of the new civil and security force and action on the

\footnotetext{
${ }^{12}$ http://www.msz.gov.pl/editor/files/docs/DPB/polityka_bezpieczenstwa/NATO_handbook.pdf.

${ }^{13}$ Ibidem.

${ }^{14} \mathrm{http} / / / \mathrm{www}$.nato.int/kosovo/history.htm.
} 
instructions of the North-Atlantic Council, began immediately the preparations for the fast development of Security Force, to operate under the mandate of ONU Security Council ${ }^{15}$.

\section{Stabilizing force of NATO - KFOR}

The first KFOR troupes entered Kosovo on June $12^{\text {th }} 1999$. The development of KFOR troupes was synchronized upon the leaving of Serbian forces from Kosovo. On June $20^{\text {th }}$, the Serbian withdrawal ended, and KFOR had accomplished the initial mission of force development. The KFOR mission included: providing assistance with respect to the return of refugees and their protection; reconstruction and clearing the conflict areas; providing medical assistance; providing security and public order; providing security to minority ethnies; imposing interdiction armament traffic; protection of national patrimony; insuring the security of borders; armament destruction; supplying support to determine some civil institutions, protection of law and order, criminal and judicial system, electoral process and other issues of political, economic and social life of province ${ }^{16}$.

The current missions of KFOR focus on constructing a safe space where all citizens, regardless the ethnie, cohabit peacefully, as well as providing support for the construction of a democratic civil society. Also, a special attention is still paid to minorities, this including patrol missions in the areas where these are determined, points of verification, providing escort to minority groups, protection of patrimony places and protection of the places where cloths and food are donated ${ }^{17}$.

Initially, the KFOR mission was formed of 50,000 militaries, staff coming from the NATO member states, partner countries as well as NATO non-member countries, gathered under the Commandment of unified control. At the beginning of 2002, the KFOR contingent was reduced to 39,000 militaries. The improvements in the security environment allowed NATO to reduce the KFOR troupes to around 26,000 militaries, starting with June 2003, and, at the end of 2003, the number of troupes reached to 17,500. A step behind in the process of stabilization of the region was taken in March 2004, when new violence acts appeared between the Albanians and Serbians, and the KFOR forces were attacked. This determined NATO to increase the number of the existent troupes by another 2,500 militaries to consolidate KFOR. At the Summit from Istanbul in 2004, the NATO leaders and the governments of NATO member states condemned vehemently the ethnic violence from Kosovo from March 2004 and acknowledged the position of KFOR in the area, necessary to create a stable and multi-ethnic Kosovo. In August 2005, the North-Atlantic Council decided the reorganization of KFOR. Thus, the 4 multi-national divisions were turned into 5 military formations ${ }^{18}$ much more flexible, which allowed the military operations register much more success and to exist a better cooperation with the police and the local population. In 2006, NATO committed solemnly to continue to assure the military presence in the area, as much as the year 2007 is the year when it was decided the future status of Kosovo province ${ }^{19}$.

The situation from Kosovo is closely supervised by the North-Atlantic Council. During the ministerial meeting from 2000, the NATO member states reasserted their decision to fully contribute to the achievement of the objectives of international community, as provided in the Resolution 1244, to take all necessary measures to turn the Kosovo province in a peaceful, democratic, multi-ethnic and multi-cultural territory, where all inhabitants could enjoy the fundamental rights and liberties. The ministers of exterior of NATO expressed their firm support for the duty undertaken by UNMIK and by the Special Representative of the

\footnotetext{
${ }^{15}$ Ibidem.

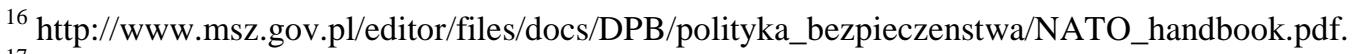

${ }^{17} \mathrm{http}: / /$ www.nato.int/kfor/.

${ }^{18}$ Task Force - military term for a military formation which involves a combination of terrestrial, naval and air units.

${ }^{19}$ http://www.nato.int/kfor/.
} 
General Secretary of ONU, as well as for the continuation of the collaboration on high level between UNMIK and KFOR. Also, they reasserted their decision to assure the maintenance of forces and capacities of KFOR on all levels required by the challenges which it should face.

\section{Conclusions}

On NATO Summit from Istanbul ${ }^{20}$ dated June 2004, the heads of states and government of the state members condemned the ethnic violence from March 2004 and reasserted the commitment of the Alliance for a safe, stable and multi-ethnic Kosovo on the grounds of a complete implementation of the Resolution 1244, and on Riga, in November 2006, NATO expressed the decision to continue to assure a security climate in Kosovo and to contribute to the implementation of the security issues of the future solution concerning the status of such province, in collaboration with ONU, EU and OSCE ${ }^{21}$.

\section{Bibliography}

Diaconu Ion, Treaty of international law, vol. I - III, Lumina Lex Publishing

House, Bucharest, 2005;

Jura, Cristian, Role of non-governmental organization on international plan, All

Beck Publishing House, Bucharest, 2003;

Năstase, Adrian, Aurescu, Bogdan, Jura, Cristian, Public international law syntheses for exams, ALL Publishing House, Bucharest, 2000;

Cassese, Antonio, International Law, Oxford University Press, 2001;

Rehman, Javaid, The weakness in the international protection of human rights, Kluwer Law Internat., 2000;

Salmon, Trevor, Issues in International Relations, Routledge, 2000;

Alston, Philip, The EU and Human Rights, Oxford University Press, 1999;

Buzan, Barry, Ole Weaver and Jaap de Wilde, Security: a new framework for analysis, Lynne Rienner Publishers, London, 1998.

\footnotetext{
${ }^{20}$ The Summit from Istanbul was organised between June $28^{\text {th }}-29^{\text {th }} 2004$ and gathered for the first time the heads of state and government of the member states of NATO under the form of the 26 member states. The decisions taken in Istanbul advanced the process of transformation launched at the Summit from Prague in 2002, reasserting the global increasing role of NATO and announcing a change in the priorities of the Alliance concerning some political fields. The allied leaders reasserted the long term importance of trans-Atlantic relation and of sharing the same trans-Atlantic values and tried to create means of cooperation with other regions.

Also, in Istanbul, the Alliance leaders launched the Initiative of Cooperation from Istanbul, which has as purpose the promotion of cooperation with the interested countries from the extended Middle Orient, starting with the countries of the Council of Cooperation of Gulf, in order to consolidate the security and stability through a new trans-Atlantic commitment in the same region. The main objectives of the initiative are: reform of defense; planning the defense; civil-military relations; fight against terrorism and illegal traffic, by exchange of information and maritime cooperation; ,mil to mil" cooperation and non-proliferation of the weapons of mass destruction.

${ }^{21}$ http://www.nato.int/docu/nato_after_riga/nato_after_riga_en.pdf.
} 